\title{
Identification of Land Areas Suitable for Fadama Farming at Federal University of Agriculture, Abeokuta, Nigeria using GIS \\ *11UFOEGBUNE, GC; FABIYI, S
}

\author{
Department of Water Resources Management and Agrometeorology, \\ Federal University of Agriculture, Abeokuta \\ *gidufoes2000@yahoo.co.uk
}

\begin{abstract}
Fadama farming provides a platform for sustained crop cultivation during dry season. This research was directed towards identifying new land areas within the Federal University of Agriculture with the use of Geographical Information System (GIS). The few existing Fadama sites within the study area were searched and their corresponding sizes were determined and represented in a map, using the tool of GIS. The drainage map of the study area was also created using Arcview. Proper digitizing and geeoreferenceing was done for the study area using GIS software and further GIS operations such as overlay and buffering were performed. The data from these operations were finally superimposed with the soil series of the study area to identify new land areas that were suitable for Fadama farming. The results produced a total of 21 areas suitable for Fadama farming in the study area. The result eventually revealed the capacity of Geographical Information System and how its analysis enable us to interpolate, combine and compare this spatial data to achieve the aim of site selection. It helped to identify new sites that can be used for Fadama practise expanding the scope of Fadama farming in the Federal University of Agriculture Abeokuta ultimately enhancing revenue generation and the society's need for food security. Management of these wetland ecosystems requires an understanding and mapping of the spatial distribution of their resources and how they are current being utilized. The geographical information system is a tool for agriculturists to utilize its potential for future production. CJASEM
\end{abstract}

http://dx.doi.org/10.4314/jasem.v20i4.15

Fadama farming is one of the rarest agricultural practices in Nigeria, yet it can be one of the most advantageous in that it favours cultivation of wetland crops such as rice and sugarcane production. Fadama which is a local name for wetlands is mostly practiced at the Northern part of Nigeria but its potentials can also be fully exploited in the SouthWestern region of Nigeria of which The Federal University of Agriculture Abeokuta short named FUNAAB can be a potential prototype of extensive wetland cultivation for National economic growth. In this study, the term wetland and Fadama are used interchangeably. The use of Geographical information system can be very useful in siting or identify land areas that can be used for Fadama farming.

Geographic Information System (GIS) is now providing new tools for advanced ecosystem management. The collection of remotely sensed data facilitates the synoptic analyses of Earth - system function, patterning, and change at local, regional and global scale over time. Such data also provide an important link between intensive, localized ecological research and regional, national and international conservation and management of biological diversity (Wilkie and Finn, 1996).

GIS with the use of Remote Sensed data can provide a general extensive synoptic coverage of large areas than aerial photography.

Identifying land areas for a specific purpose using GIS packages is known as Site Selection. Site selection involves the use of spatial data which is also known as geospatial data or information that identifies the geographic location of physical features on the earth. This spatial data is accessed, manipulated or analysed through Geographical Information System.

Fadama farming is poorly practiced in the SouthWestern region of Nigeria. This implies underutilization of wetlands (Fadama) in the SouthWestern part of Nigeria. FUNAAB being a Federal University of Agriculture can become a forerunner in wet land cultivation in the South-Western region of Nigeria. FUNAAB can also become more profitable and industrial if wetland (Fadama) cultivation is practiced more extensively. Hence, there arises a need to identify more wetland for Fadama farming in FUNAAB.

It is observed that very few wetlands are currently in use for Fadama farming in FUNAAB, the total size of which is only approximately one hectare. This means that the total land resource of FUNAAB is underutilized considering the total land areas of FUNAAB which is about 10,000 hectares having drainage basins with several tributaries giving a foresight of how suitable FUNAAB wetlands are and how agriculturally productive FUNAAB can be if these wetlands are properly exploited for the purpose of Fadama farming.

In recent times, the Niger-based African centre of Meteorological Application for Development and the Regional Centre for Mapping of Resources for Development in Kenya have both done much to 
promote Remote Sensing through capacity building and advisory services (Spore, 2012).

Geographic information system (GIS) on the other hand is a system designed to capture, store, manipulate, analyze, manage, and present all types of geographical data.

Study Area: The Federal University of Agriculture, Abeokuta is located next to Ogun-Osun River Basin Development Authority (OORBDA), along OsieleAbeokuta road, off Abeokuta-Ibadan road in the north Eastern end of the city at Alabata and is from the city center of Abeokuta which lie approximately on latitude $7^{0} 30^{\prime} \mathrm{N}$ and longitude $3^{0} 54^{\prime} \mathrm{E}$. It lies within the humid lowland rain forest region with two distinctive seasons. The wet season extends from March to October while the dry season extends from November to February. The mean annual rainfall is $1113.1 \mathrm{~mm}$. The rainfall has a characteristic bimodal distribution with peaks in July and September and breaks in August. Generally, the rainfall could be heavy and erosive sometimes accompanied by lightning and thunderstorm at the beginning and the end of rainy season. The mean monthly temperature varies from $22.9^{\circ} \mathrm{C}$ in August to $36.32^{\circ} \mathrm{C}$ in March. The relative humidity is high ranging from $75.52^{\circ} \mathrm{C}$ in February to $88.15^{\circ} \mathrm{C}$ in July (Aiboni, 2001). The vegetation of the area comprises of low land forest but become secondary rainforests or forest re-growth because of the increase in land use and exposure. The vegetation has the characteristics of tropical rain forest such as high forest and growth of massive trees and twinning shrubs. The forest is covered with litters of fallen trees by both human and natural activities. The Federal University of Agriculture, Abeokuta, Ogun State, overlies the pre-Cambrian metamorphic rocks of the basement complex (Jones, 1964), with biotitic hornblende gneisses, quartzite and quartz schist. Physical structures and facility available include, academic core, unity building, lecture theatre rooms, institutes, strict nature reserve, farm centre etc. as well as existing rivers/streams which included rivers Oshinko, Ole/Alakata, Arakanga, Pala, Pap/Olu and Tigba/Ajigbayin.

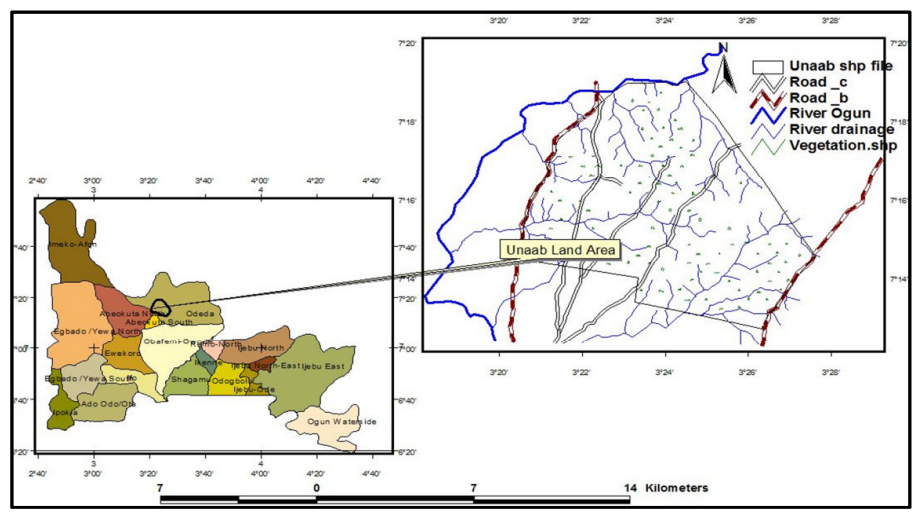

Fig 1: Map of Ogun State showing the study area.

\section{MATERIALS AND METHODS}

Materials: The materials used in carrying out this project include:

Hardware: The hardware used in this study includes

Asus x551c, scanner, Garmin 12x Global Positioning System (GPS) device, Camera (8mp) and colour printer.

Software: The software used in preparing and analysis of the data include ILWIS 3.2, ArcView 3.2a and Google earth pro ${ }^{\mathrm{TM}} 2007$.

Data Source: Spatial Data, The spatial data includes information acquired with the aid of a handheld G.P.S (Global Positioning System) device during field data collection and ground truthing. The coordinates read in decimals degrees. Topographical maps, Abeokuta NE Sheet 260 and Abeokuta SE Sheet 260 at a scale of 1:50000 were obtained from the Cartographic
Laboratory of the Department of Water Resources Management and Agrometeorology were scanned and used for the study. High resolution image obtained from Google Earth Archives. Global Positioning System (G.P.S) was used to collect coordinates of important features found in the study area. The GPS was also used for tracking major developmental activities and projects taking place in the study area.

Method: Data Processing and Analysis; The coordinates of FUNAAB land features was taken with the Global Positioning System (GPS) during ground truthing and was transferred into a spreadsheet (M. S. Excel) and developed into Text Tab Delimited file which is readable. The coordinates were imported into the GIS software (Arc view 3.2) through a module (Add Event Theme) in the software (Arc view 3.2) and the high resolution image (JPEG 
FORMAT) was imported into Arc view as another theme.

Georeferencing of the Satellite Images: The scanned maps were georeferenced using Ilwis 3.2 and exported into arcview $3.2 \mathrm{a}$ for further image processing. Georeferencing means aligning geographic data to a known coordinate system so that it can be viewed, queried and analyzed with other geographic data. Georeferencing may involve shifting, rotating, scaling, skewing and in some cases warping, rubber sheeting or orthorectifying the data.

Topographical Map Processing (Digitising): The topographical maps that cover the study area are Abeokuta S.E. (Sheet 260) and Abeokuta N.E. (sheet 260). The area of the study interest was delineated using corner coordinates on the topographical sheets, later scanned and imported into the ArcView 3.2 environment as jpeg file format for georeferencing using land cover features such as, road intersect and drainage inside the toposheet. This was followed by on-screen digitizing the existing features of land cover categories on the topographical map.

Digitising is the process of encoding geographical features in digital form as $\mathrm{X}$ and $\mathrm{Y}$ coordinates. To digitize, we first converted the satellite imagery to SHAPEFILES which is now selected on view bar. Important features are digitized on the images (Land sat TM and High resolution images) using the digitizing tool icon which are; split polygon, zoom (in and out), Draw polygon, append polygon, pointer, vertex Edit.

Buffering Analysis: Buffering is the use of an analytical extension in Arcview 3.2a to identify land areas by use of inputted parameters to outline extended regions of flood plains of the most viable tributaries on the DTM map which can be used sustainably for Fadama practice even during flood or during dry season.

The buffering operation is a spatial operation used to determine the spatial proximity or nearness of various geographical features to one another. The operation performed by buffer command generates one or more polygons surrounding existing geographic features and the polygon is called BUFFER or BUFFERD ZONE.

In this study, the river layer was buffered by $100 \mathrm{~m}$ to highlight perimeters with good moisture.

Overlaying Operations: New map features were created by overlaying features from different themes representing different datasets. Attributes of each theme features are combined from the two data sets to describe each new output theme feature.
Topological overlay can be used for a number of objectives such as theme updating, feature extraction, merging adjacent themes and merging feature attributes. However, the topological overlays used for this study include union and extraction. The union computes the geometric intersection of two coverages and preserves all features and attributes of both coverages.

Overlay operations carried out in this study include:

Overlay of contour and drainage map

Overlay of Buffer zone with contour and drainage map

Procedure: Inquiries and survey for existing Fadama sites was done and ground truthing using a GPS device was used to get their geographical location (Latitude and Longitude) of the obtained places.

Topographic map and drainage map of the study area is gotten from the physical planning unit of the university. The maps were then scanned and imputed into Ilwis 3.2 environment where they were georeferenced.

The scanned georeferenced map is then digitised on the Arcview 3.2a platform to create SHAPEFILE.

The digitised maps include: The boundaries of the study area (FUNAAB) Contour map of the study area; River Drainage of the study area

The boundary SHAPEFILE for the study area was exported into Google Earth Pro ${ }^{\mathrm{TM}} 2007$ to show the study area on from a satellite view.

The existing sites are indicated on the map on Google Earth and their corresponding area is measured using the measurement tool on Google Earth software.

Reconnaissance observation of new wetland suitable for Fadama but the areas accessible were limited due to road access.

Interpolation of drainage map with the existing and reconnaissance Fadama sites was done by overlay operations of the SHAPEFILE created for the drainage map and new points.

Buffering analysis was conducted; query analysis was also to be performed but couldn't be done because there was no open source of ready data set attributes.

The overlaying of the contour and drainage map was used at the Digital Terrain Model for this study.

After buffer of drainage was done for $100 \mathrm{~m}$ perimeter, new sites were carefully selected carefully considering the buffer with lowlands area within two or more tributaries for effective water availability. 


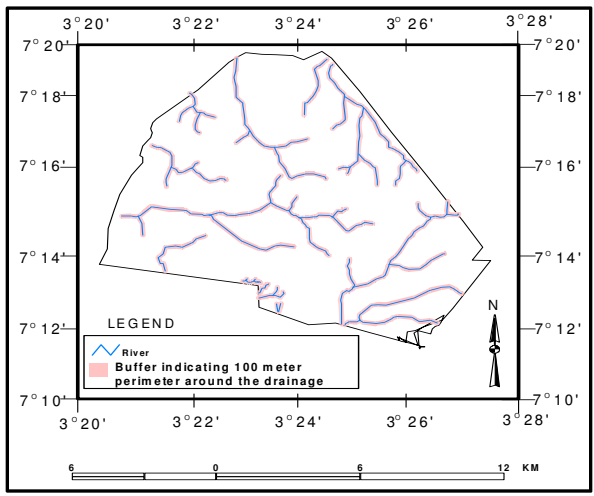

Fig 2: Showing the result of buffer of drainage done Arcview 3.2a

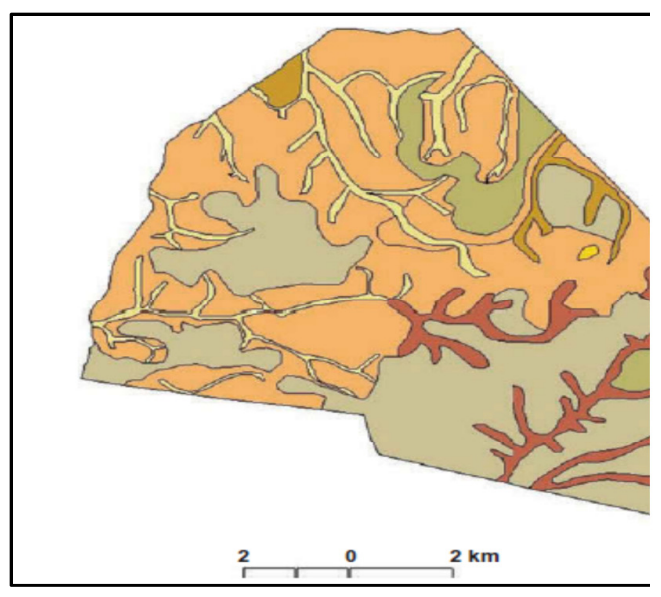

Fig 4: (Color online) Soil series at the area of the Federal University of Agriculture, Abeokuta, Southwestern Nigeria.

Source: T. Sotona et al. (2013).

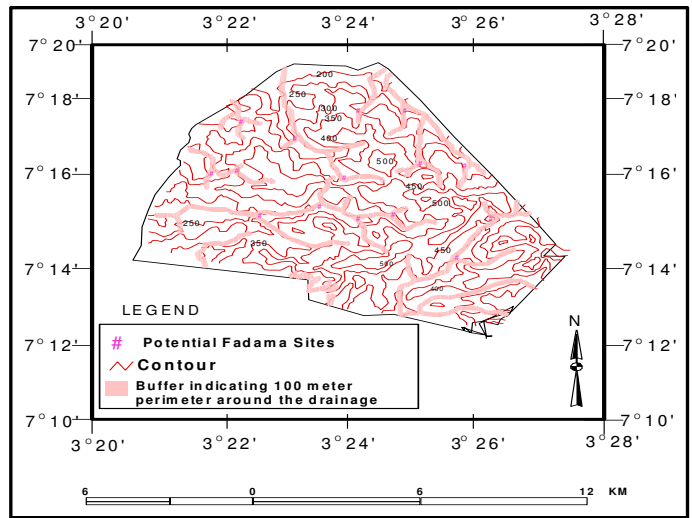

Fig 3: Showing new sites selection by overlay of buffer and contour of study area

\begin{tabular}{|c|c|c|c|}
\hline $\begin{array}{l}\text { Local } \\
\text { series }\end{array}$ & $\begin{array}{c}\text { USDA } \\
\text { equivalent }\end{array}$ & $\begin{array}{c}\text { FAO/UNESCO } \\
\text { equivalent }\end{array}$ & Description \\
\hline Apomu & Oxic Paleustalf & Ferric Luvisols & $\begin{array}{l}\text { Derived from colluvial materials; occupy moderate to gentle slopes; very sandy to a depth of } \geq 50 \mathrm{~cm} \text {; free of } \\
\text { stones and concretions. }\end{array}$ \\
\hline Egbeda & $\begin{array}{l}\text { Rhodic } \\
\text { Paleustalf }\end{array}$ & Ferric Lixisols & $\begin{array}{l}\text { Occupy level to gentle slopes; bright orange } \\
\text { to brownish red between } 25 \text { and } 120 \mathrm{~cm} \text { depth. }\end{array}$ \\
\hline Ekiti & $\begin{array}{l}\text { Lithic } \\
\text { Troporthent }\end{array}$ & Lithosols & $\begin{array}{l}\text { Skeletal in nature and of comparative recent origin; occurrence is limited to small patches close } \\
\text { to exposed rock surfaces usually on hill summits. }\end{array}$ \\
\hline Iseyin & Oxic Ustopept & Ferric Cambisols & Hill creep soils; pale grayish brown to dark reddish brown; sandy clay to clay. \\
\hline Iwo & $\begin{array}{l}\text { Kandic } \\
\text { Paleustalf }\end{array}$ & Ferric Lixisols & $\begin{array}{l}\text { Occupy level or gentle siopes; profile is grayish brown to brownish red; fairly clayey within } 50 \mathrm{~cm} \text {; } \\
\text { sand fraction is usually coarse and small fragments of feldspar are often present. }\end{array}$ \\
\hline Jago & $\begin{array}{l}\text { Paleustait } \\
\text { Typic }\end{array}$ & Gleyic Luvisols & $\begin{array}{l}\text { Sand fraction is usually coarse and small fragments of ectuspar are often present. } \\
\text { Occupy gentle to level slopes; usually close to temporary to perennial streams; pale }\end{array}$ \\
\hline Okemesi & $\begin{array}{l}\text { Tropaquali } \\
\text { Oxic Tropudalf } \\
\text { sites }\end{array}$ & Ferric Luvisols & $\begin{array}{l}\text { grayish brown to pale yellowwish brown and yellow color being common. } \\
\text { Occupy steeply sloping sandy, not heavier than clayey sand on the horizons above } 45-50 \mathrm{~cm} \text {; } \\
\text { usually shallow and very stony. }\end{array}$ \\
\hline
\end{tabular}

Source: T. Sotona et al. (2013) 


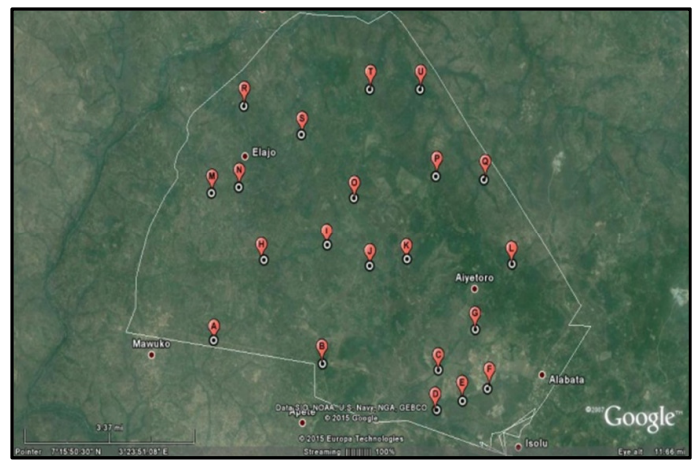

Fig: 5 Satellite imagery showing all new sites consider suitable for Fadama farming in the study area Source: Google Earth Pro ${ }^{\mathrm{TM}} 2007$

\section{RESULTS DISCUSSION}

The result is significant as it reveals the capacity of Geographical Information System and how its analysis enable us to interpolate, combine and compare this spatial data to achieve the aim of site selection.

This study is also unique in its approach creating buffering zone within 100 meter perimeter slightly varying from the recommendation of Adeofun et al (2006) and Sani et al (2010) for buffering of $160 \mathrm{~m}$ distance indicating the limits of infiltration of nearby rivers when siting disposal sites. This was to enhance accuracy in decision and to ensure that the zones suggested by the buffer have assurance of constant percolation of water from the nearest river basin to the points that will be chosen. The study reveal additional new sites that can be used for Fadama practise expanding the scope of Fadama farming in the Federal University of Agriculture Abeokuta ultimately enhancing revenue generation and the society's need for food security similar to the research done by Wood, A. (2006) on the environmental role of wetlands in headwaters where it was indicated that wetlands in sub-Saharan Africa typically play a vital role in supporting rural populations, the sustainable management of these ecosystems is critical. In order to prevent depletion of these resources a balance is required between environmental and socio-economic needs (Wood, 2006).

Table 4: New Sites selected suitable for Fadama Farming within the Federal University of Agriculture.

\begin{tabular}{|c|c|c|c|}
\hline \multirow{2}{*}{\multicolumn{2}{|c|}{ Site }} & \multicolumn{2}{|l|}{ Location } \\
\hline & & Latitude & Longitude \\
\hline & $\mathbf{A}$ & $7^{\circ} 14^{\prime} 11.13 " \mathrm{~N}$ & $3^{\circ} 21^{\prime} 27.46^{\prime \prime E}$ \\
\hline & B & & \\
\hline & $\begin{array}{l}\text { C } \\
\text { D }\end{array}$ & $7^{\circ} 13 ' 53.19 " \mathrm{~N}$ & $3^{\circ} 23^{\prime} 20.36 " \mathrm{E}$ \\
\hline & $\mathbf{E}$ & $7^{\circ} 13^{\prime} 45.49 " \mathrm{~N}$ & $3^{\circ} 25^{\prime} 21.86^{\prime \prime} \mathrm{E}$ \\
\hline & $\mathbf{F}$ & $7^{\circ} 13^{\prime} 10.33 " \mathrm{~N}$ & $3^{\circ} 25^{\prime} 18.70^{\prime \prime E}$ \\
\hline & G & $7^{\circ} 13^{\prime} 20.69^{\prime \prime N}$ & $3^{\circ} 25^{\prime} 46.86 " \mathrm{E}$ \\
\hline & $\mathbf{H}$ & $7^{\circ} 13^{\prime} 32.66 " \mathrm{~N}$ & $3^{\circ} 26^{\prime} 15.30^{\prime \prime} \mathrm{E}$ \\
\hline & I & $7^{\circ} 14^{\prime} 22.60 " \mathrm{~N}$ & $3^{\circ} 26^{\prime} 0.34^{\prime \prime} \mathrm{E}$ \\
\hline & $\mathbf{J}$ & $7^{\circ} 15^{\prime} 24.57^{\prime \prime N}$ & $3^{\circ} 22^{\prime} 17.08^{\prime \prime E}$ \\
\hline & $\mathbf{K}$ & $7^{\circ} 15^{\prime} 37.19 " \mathrm{~N}$ & $3^{\circ} 23^{\prime} 25.33^{\prime \prime E}$ \\
\hline & $\mathbf{L}$ & $7^{\circ} 15^{\prime} 18.84 " \mathrm{~N}$ & $3^{\circ} 24^{\prime} 10.44^{\prime \prime E}$ \\
\hline & M & $7^{\circ} 15^{\prime} 23.42 " \mathrm{~N}$ & $3^{\circ} 24^{\prime} 48.62^{\prime \prime} \mathrm{E}$ \\
\hline & $\mathbf{N}$ & $7^{\circ} 16^{\prime} 19.65 " \mathrm{~N}$ & $3^{\circ} 23^{\prime} 46.15^{\prime \prime} \mathrm{E}$ \\
\hline & $\mathbf{O}$ & & \\
\hline
\end{tabular}




\begin{tabular}{|c|c|c|}
\hline $\bar{P}$ & $7^{\circ} 16^{\prime} 32.27^{\prime \prime N}$ & $3^{\circ} 21^{\prime} 53.94 " \mathrm{E}$ \\
\hline Q & $7^{\circ} 16^{\prime} 32.27 " \mathrm{~N}$ & $3^{\circ} 21^{\prime} 53.94 " \mathrm{E}$ \\
\hline $\mathbf{R}$ & $7^{\circ} 16^{\prime} 20.80^{\prime \prime} \mathrm{N}$ & $3^{\circ} 23^{\prime} 54.25 " \mathrm{E}$ \\
\hline $\mathbf{S}$ & $7^{\circ} 16^{\prime} 42.86 " \mathrm{~N}$ & $3^{\circ} 25^{\prime} 20.44^{\prime \prime} \mathrm{E}$ \\
\hline $\mathbf{T}$ & $7^{\circ} 16^{\prime} 39.97 " \mathrm{~N}$ & $3^{\circ} 26^{\prime} 11.07 " \mathrm{E}$ \\
\hline \multirow[t]{4}{*}{$\mathbf{U}$} & $7^{\circ} 17^{\prime} 45.76 " \mathrm{~N}$ & $3^{\circ} 21^{\prime} 59.13^{\prime \prime E}$ \\
\hline & $7^{\circ} 17^{\prime} 18.64 " \mathrm{~N}$ & $3^{\circ} 22^{\prime} 59.65^{\prime \prime} \mathrm{E}$ \\
\hline & $7^{\circ} 18^{\prime} 0.66 " \mathrm{~N}$ & $3^{\circ} 24^{\prime} 11.14 " \mathrm{E}$ \\
\hline & $7^{\circ} 18^{\prime} 0.77^{\prime \prime N}$ & $3^{\circ} 25^{\prime} 3.62^{\prime \prime} \mathrm{E}$ \\
\hline
\end{tabular}

Also the need for capacity building is necessary, the need to develop national and local community capacity to undertake analyses and interpret the responses in a local operating environment. This is in line with international emphasis on developing capacity within countries to undertake wetland inventory and assessment and to ensure that local communities are involved at all stages of the analyses and can make use of the outcomes (Fernandez-Prieto et al., 2006). The capacity building component of the present assignments involves a number of stages; involvement of stakeholders, local partners and/or planners in planning and implementing the project and specific components, assisting with interpretation and the development of models for predictive analyses, and importantly,

in the transfer of information and outcomes to the wider community. (Rebelo L.M. et al., 2007). There are many examples though where this has not been done successfully (Carbonell et al., 2001), but it is acknowledged as part of the global wetland inventory

project that the establishment of effective relationships with stakeholders along with the technical analyses is an important component. (Rebelo L.M. et al., 2007).

\section{REFERENCE}

Adeofun, C.O. and Nwagu, C.J. (2006). Selection of Solid Waste Landfill Site Using Remote Sensing and GIS Techniques. Asset Series A 6 (2): 301310 .

Aiboni V. U. (2001). Characteristics and classification of soil of a representative topographical location in University of Agriculture, Abeokuta. Asset Series A 1(1): 5161.

Carbonell, M., Nathai-Gyan, N., Finlayson, C.M. (Eds.), 2001. Science and Local Communities: Strengthening Partnerships for Effective Wetland
Management. Ducks Unlimited Inc., Memphis, USA, 93 pp.

Fernandez-Prieto, D., Arini, O., Borges, T., Davidson, N., Finlayson, M., Grassl, H., MacKay, H., Prigent, C., Pritchard, D., Zalidis, G., 2006. The GlobWetland Symposium: Summary andWay Forward. Proceedings GlobWetland: Looking at Wetlands from Space, October 2006, Frascati, Italy.

Jones H.A, Hockey R.D (1964). The Geology of part of Southwestern Nigeria; Geological Survey of Nig. Bull, 31: 101-104.

Rebelo L.-M., Finlayson C.M. and Nagabhatla N. 2007. Remote sensing and GIS for wetland inventory, mapping and change analysis. International Water Management Institute, Colombo, Sri Lanka. Available from:< http://www.elsevier.com/locate/jenvman>

Spore, 2012 ( The magazine for Agriculture and Rural Development in ACP countries, http://spore.cta.int (vol15)

Titilayo Sotona, Felix Kolawole Salako \& Johnson Kayode Adesodun (2014) Soil physical properties of selected soil series in relation to compaction and erosion on farmers' fields at Abeokuta, southwestern Nigeria, Archives of Agronomy and Soil Science, 60:6, 841-857, DOI: $10.1080 / 03650340.2013 .844334$

Wilkie, D.S. and Finn, J.T. (1996). Remote Sensing Imagery for Natural Resources Monitoring. Columbia University Press, New York. p. 295.

Wood, A., 2006. Environmental role of wetlands in headwaters. NATO Science Series IV 63, $211 \mathrm{e} 220$. 